\title{
大腸癌腹膜播種再発にともなう腸閉塞に対する治療方針について （栄養評価からの検討）
}

\author{
谷村修星野誠一郎愛洲 尚哉吉田陽一郎 \\ 別府理知子 田中伸之介山下裕一 \\ 福岡大学消化器外科
}

目的：大腸癌における腹膜播種再発による腸閉塞は, 改善する見込みがほとんどなくその全身状態から 手術適応についても迷うことも多い. 方法：腸閉塞症例 14 症例の栄養指数 (PNI：prognostic nutritional index) 40 以上と 40 未満の 2 群，手術施行例と非施行例の 2 群に分類し生存期間の比較検討を行った. 結 果：PNI：40 以上であれば手術することにより 120 日以上の生存期間が得られる可能性が示唆された.

索引用語：大腸癌, 腹膜播種再発, PNI

\section{はじめに}

大腸癌における腹膜播種再発は予後不良であり時 に腸閉塞を合併する．腸閉塞は改善する見込みはほ とんどなく手術を行うか否か判断に迷うことが多 い.

今回我々は，大腸癌術後腹膜播種再発を呈し，腸 閉塞を来たした 14 症例について背景, 全身状態, 手 術の有無，栄養指数 (PNI) そして予後について検討 した。

\section{対象および方法}

福岡大学病院において大腸癌の手術を行い 1999 年 4 月から 2009 年 4 月までに術後腹膜播種再発に よる腸閉塞を来した 14 症例を対象とした. 腹膜播種 再発の診断は, CT, MRI などの画像診断, 手術症例 においては画像診断に加え開腹所見にて複数の再発 病巣を認めたものとした。吻合部近傍の再発は局所 再発として除外している。腸閉塞の定義は，その播 種病変により腸管の通過障害を来たし経口摂取不可 能な症例とした。また生存期間は，手術症例，非手 術症例とも腸閉塞の診断し入院してから死亡するま での期間（日）とした。

初回手術から腸閉塞を来した期間, 腸閉塞に対し て手術の有無, 平均 BMI, 平均 PNI, 腸閉塞と診断 (入院)してからの平均生存期間を 120 日以上生存し
た群と 120 日未満の群の 2 群に, さらに手術施行例 と非施行例の 2 群に分けてそれぞれ比較検討を行っ た.

統計学的処理は Student's t-test, Fisher's exact probability test を用いて，2 群間の有意差を検定し 累積生存率は Kaplan-Meier 法を用いて Log-rank 検定を行い，いずれの検定も $\mathrm{p}<0.05$ で有意差あり と判定した.

\section{結 果}

腹膜播種再発による腸閉塞を来した 14 症例は男 性 8 症例, 女性 6 症例であり, 原発巣は直腸 5 症例, $\mathrm{S}$ 状結腸 4 症例，上行結腸，横行結腸がそれぞれ 2 症例であり盲腸が 1 症例であった。組織型は中分化 型腺癌が最も多く 14 症例中 8 症例を占めた. 14 症 例中 10 症例に術後化学療法を行っている. 初回手術 から腸閉塞を来たした平均期間は 1,057 日であった (表 1).腸閉塞から 120 日以上生存した 5 症例と 120 日未満の生存例 9 症例の比較検討を行った。ただし 腹水の程度, $\mathrm{P}$ については正確な評価が困難であっ たため有意差は検定していない，2 群間の比較にて 腸閉塞に対する手術の有無と平均 PNI 值に有意差 を認めた（表 2)。この 2 群間での累積生存率を比較 してみると術前の栄養状態（栄養指数：PNI：40 以 上）の良い症例が 120 日以上生存する可能性が示唆 された（図 1)。次いで手術群 6 症例と非手術群 8 
表 1 大腸癌術後腸閉塞を来した 14 症例

\begin{tabular}{|c|c|c|c|}
\hline 男女比 & 男性：女性 8:6 & & \\
\hline 原発巣 & $\begin{array}{l}\text { 盲腸 } \quad: 1 \text { 症例 } \\
\text { 上行結腸: } 2 \text { 症例 } \\
\text { 横行結腸: } 2 \text { 症例 }\end{array}$ & $\begin{array}{l}\mathrm{S} \text { 状結腸 } \\
\text { 直腸 }\end{array}$ & $\begin{array}{l}: 4 \text { 症例 } \\
: 5 \text { 症例 }\end{array}$ \\
\hline 進行度（stage） & $\begin{array}{l}\text { StageI }: 1 \text { 症例 } \\
\text { StageII }: 1 \text { 症例 }\end{array}$ & $\begin{array}{l}\text { StageIIIa } \\
\text { StageIIIb } \\
\text { StageIV }\end{array}$ & $\begin{array}{l}: 4 \text { 症例 } \\
: 2 \text { 症例 } \\
: 6 \text { 症例 }\end{array}$ \\
\hline 組織型 & $\begin{array}{l}\text { 高 ( 中 ) 分化腺癌 } \\
\text { 中分化腺癌 } \\
\text { 低分化腺癌 }\end{array}$ & $\begin{array}{l}: 3 \text { 症例 } \\
: 8 \text { 症例 } \\
: 1 \text { 症例 }\end{array}$ & $\begin{array}{l}\text { 粘液癌 }: 1 \text { 症例 } \\
\text { 腺癌 }: 1 \text { 症例 }\end{array}$ \\
\hline $\begin{array}{l}\text { 初回手術から } \\
\text { 腸閉塞をきたした平均期間（日） }\end{array}$ & $1,057.1 \quad(153 \sim 3,755)$ & & \\
\hline
\end{tabular}

表 2 生存期間による 2 群間の比較

\begin{tabular}{|c|c|c|c|}
\hline & $\begin{array}{c}\text { 腸閉塞から } 120 \text { 日未満の生存 } \\
(\mathrm{n}=9)\end{array}$ & $\begin{array}{c}\text { 腸閉塞から } 120 \text { 日以上生存 } \\
(\mathrm{n}=5)\end{array}$ & $\mathrm{P}$ \\
\hline 腹水の有無 & $7 / 9$ & $3 / 5$ & \\
\hline P3 症例 & $3 / 9$ & $3 / 5$ & \\
\hline $\begin{array}{l}\text { 腸閉塞をきたした } \\
\text { 平均期間 }\end{array}$ & 1,204 日 & 792 日 & 0.48 \\
\hline $\begin{array}{l}\text { 腸閉塞に対しての } \\
\text { 手術の有無 }\end{array}$ & $2 / 9$ & $4 / 5$ & 0.036 \\
\hline 平均 BMI 值 & 20.2 & 21.4 & 0.25 \\
\hline 平均 PNI 值 & 30.0 & 40.1 & 0.022 \\
\hline $\begin{array}{l}\text { 腸閉塞手術からの } \\
\text { 平均生存期間（日） }\end{array}$ & 55.4 日 & 326.0 日 & \\
\hline
\end{tabular}

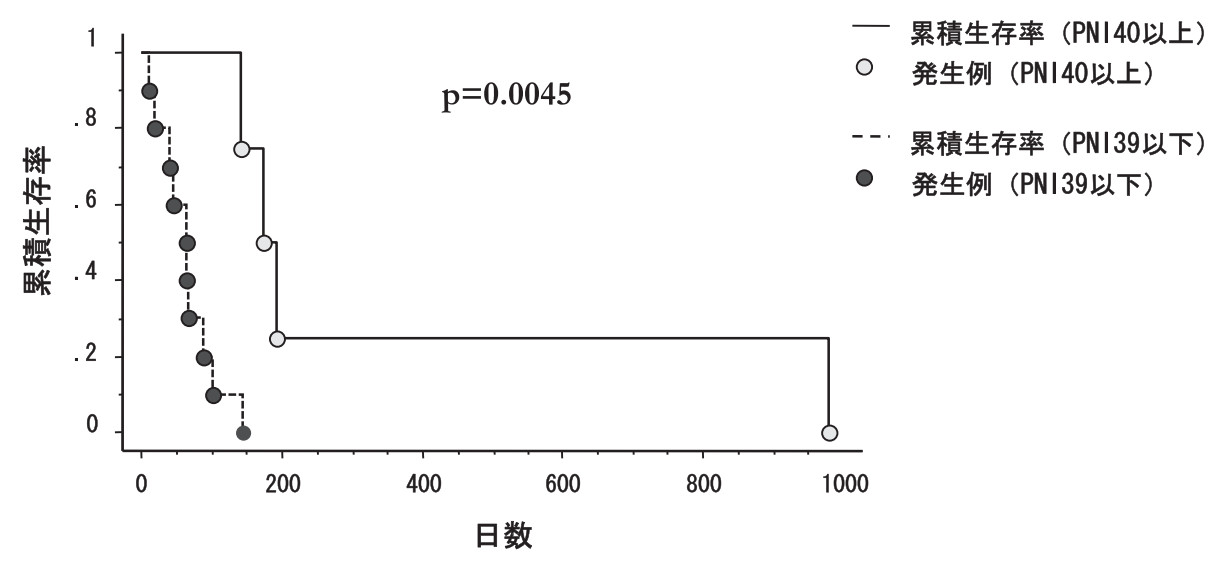

図 1 PNI40 以上と 39 以下での累積生存率

症例について再手術時の他の転移巣の有無, 腹水の 有無, BMI, PNI, 入院時採血結果などを示す. 腹水 の程度やP の評価を正確に評価することは困難で あったが, 非手術群における平均 BMI, 平均 PNI は 20.5, 28.3 であり，手術群ではそれぞれ 19.7, 38.9
であった．また手術群において入院後手術に至るま での平均期間は 8.0 日（1～17 日）であった（表 3$)$. 手術例と非手術例における腸閉塞にて入院してから 死亡するまでの累積生存率を比較すると手術症例に おいて有意に生存期間が得られた結果であった（図 
表 3 非手術群と手術群

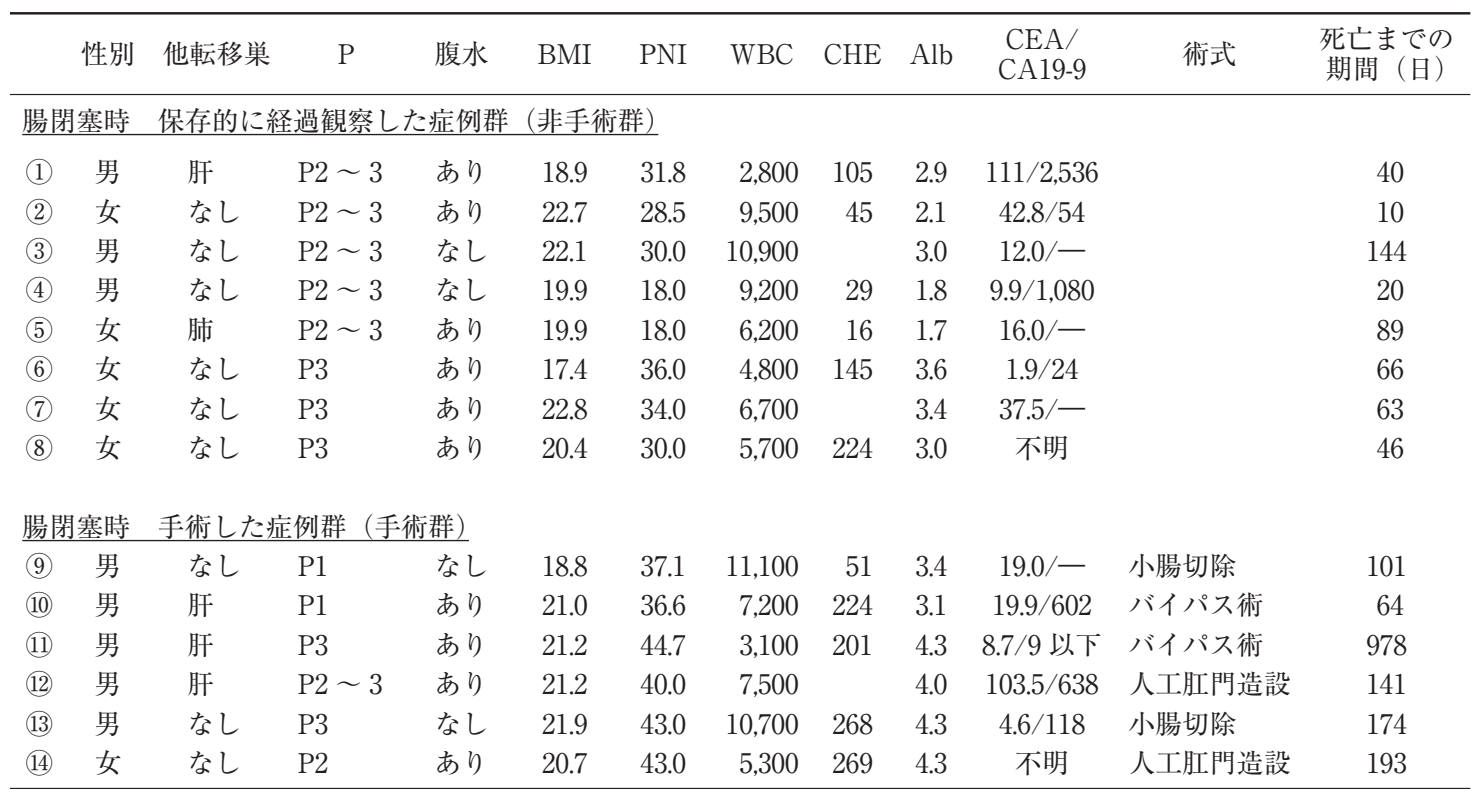

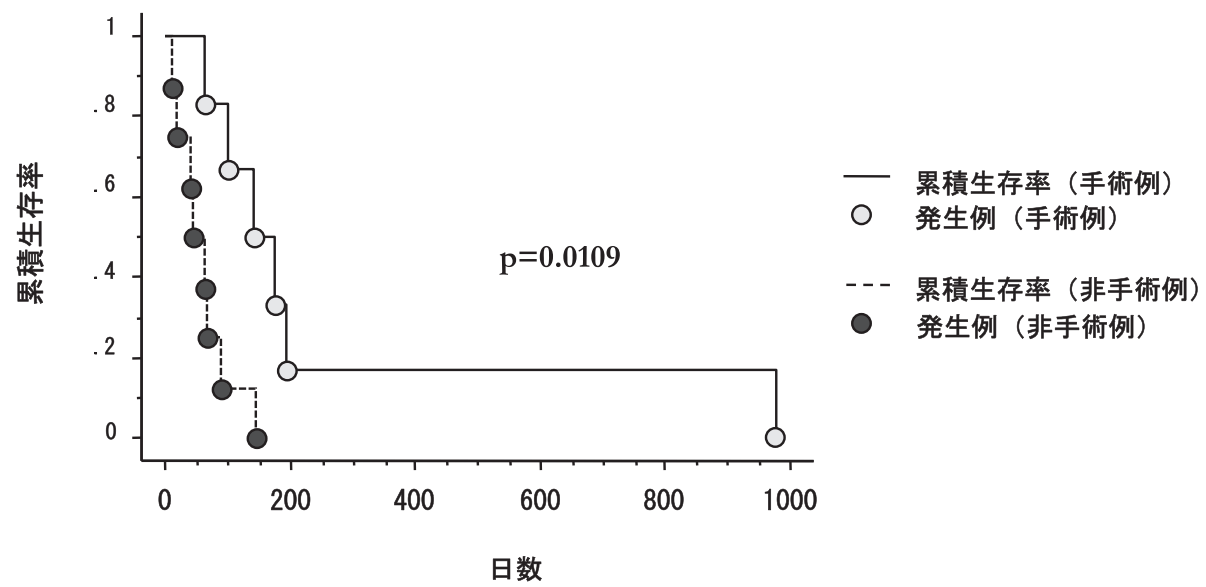

図 2 手術群と非手術群との累積生存率の比較

2).

\section{考察}

大腸癌における腹膜播種再発により腸閉塞は患者 の QOL を著しく低下させ，イレウス管を挿入し腸 管内の減圧ができたとしても, 腸閉塞が改善する例 は少なく手術以外に腸閉塞を解除することは困難な ことが多い. しかもその患者の多くは経口摂取困難 な状態に加え担癌状態のため顕著な低栄養であり， さらに悪液質をともない手術侵襲により，その生命 予後を著しく短縮することもありその適応に迷うこ とも多い.

過去の報告を検索しても原発症例，初回手術時の
腹膜播種症例の検討が多く再発かつ腸閉塞症例の検 討は散見されるのみである．加藤らは大腸癌腹膜播 種再発により腸閉塞を呈した 16 症例を検討し, 術後 200 日以上生存した症例の特徴として(1)術前 CT に て腹水を認めない(2術前 PET-CT にて病巣の指摘 が可能(3)術中播種病巣の切除が可能(4)術中の腹水が 少量といった点を挙げている ${ }^{1}$. 今回我々の検討した 14 症例は 10 症例で術前より腹水を認め播種巣の切 除は不能例であった。しかし手術にて腸閉塞の解除 を行った症例の術後平均生存日数は 275 日（978 日 生存した症例を除けば134日）であり，保存的に経 過観察を行った 8 症例の生命予後の 59 日とくらべ て手術を行い閉塞解除術を行った症例の生命予後は 
得られている，手術により生命予後の延長が得られ たか否かの判断は困難であるが，手術を行った 6 症 例は全例イレウス管を術後抜去できており，確認で きた 4 症例は一時的にせよ経口摂取が可能となって いる.

我々は手術により 4 カ月以上生存が確認できた 4 症例の特徵として栄養指数 (prognostic nutritional index : PNI) を挙げた。これは血清アルブミン值と 末梢血リンパ球数の 2 つの因子から算出される簡便 な栄養の指標であり, PNI = 10Alb + 0.005 Lymph.C (Alb : Serum albumin $\mathrm{g} / \mathrm{d} l$, Lymph.C : 抹消総リン パ球数 $/ \mathrm{mm}_{3}$ ) で表される. 消化管切除や吻合, 術後 合併症との関連も報告され比較的信頼性も高( ${ }^{2-4)}$. 消化器の手術において PNI：40４5では手術危険, 注意域, 40 以下では切除吻合禁忌域と報告されてい る．通常腹膜播種再発かつ腸閉塞をともなっている 症例において PNI は低值であり PNI：40 以下であ る場合が多い，そのような場合，今回検討した症例 ではいずれも 4 カ月以上の生命予後が得られていな い結果であった．そのためPNI：40 以下で手術に踏 み切る場合十分な IC が必要であると考えられる.

近年大腸癌の化学療法, 集学的治療の発達はめざ
ましく腹膜播種再発により腸閉塞を来した症例に対 し手術を行い術後化学療法を併用し長期間 QOL を 保ったまま経過している報告も散見される5 .これら の知見からも腹膜播種再発の腸閉塞症例でも PNI : 40 以上であれば腸閉塞解除術を行い, 術後化学療法 を組み合わせることにより長期予後が得られる可能 性があると思われる.

\section{引用文献}

1）加藤健志, 三宅泰裕, 土井貴志司ほか：大腸癌腹膜播種 再発に伴う腸閉塞に対する切除術の検討. 癌と化学療法 34 (12) : 1949-1951, 2007

2) 小野寺時夫, 五関謹秀, 神前五郎 : Stage IV ・V (V は大 腸癌）消化器癌の非治癒切除・姑息手術に対する TPN の適応と限界。日外会誌 85 (9)：1001-1005, 1984

3）佐川まさの, 勝部隆男, 今野宗一ほか : 消化管癌手術に おける小野寺式栄養指数の意義について. 癌と化学療法 35 (12) : 2253-2255, 2008

4）若林久男, 大谷 剛, 近藤明宏ほか：小野寺らの prognostic nutritional index の再評価一特に高齢者胃・大腸 癌に対する手術患者での検討. 日消外会誌 37 (5)： 472-478, 2004

5）阿美克典, 平良真博, 鴈野秀明ほか：腹膜播種切除後に 化学療法併用にて長期生存が得られている大腸癌 2 例. 癌と化学療法３4（12）：2044-2046,2007

\title{
Treatment for Peritoneal Dissemination from Metastatic Recurrent Colorectal Cancer with Ileus
}

\author{
Syu Tanimura, Seiichirou Hoshino, Naoya Aisu, Youichirou Yoshida, \\ Richiko Beppu, Shinnosuke Tanaka and Yuichi Yamashita \\ Department of Gastroenterological Surgery, Fukuoka University of Medicine
}

We studied the operative indications for peritoneal dissemination from metastatic recurrent colorectal cancer with ileus. The symptoms associated with ileus negatively affect the patient's quality of life.

It is difficult to determine the operative indications for the treatment of ileus because surgery results in a shortening of the patient's survival.

A total of 14 patients presenting with recurrent peritoneal dissemination and ileus during the period from 1999 to 2009 were operated on for colorectal cancer at Fukuoka University Hospital.

We classified the patients into two groups: those treated surgically for ileus, and those who were not.

We also classified the 14 patients into two groups: those demonstrating a PNI score of over 40, and those with a PNI score of less than 40.

Our results showed that the patients treated surgically for ileus with a PNI score of over 40 demonstrated a survival of 120 days or more. 